\title{
Erasable Ink Production for White Board Marker Using Locally
}

\section{Sourced Dye}

\author{
Nwosibe P0*, Nwafulugo FU and Iliyasu N \\ Department of Chemical Engineering, Kaduna Polytechnic, Nigeria
}

*Corresponding author: Nwosibe PO, Department of Chemical Engineering, Kaduna

Polytechnic, Kaduna, Nigeria, Phone: +2348037710269; Email: patnwosibe@gmail.com
Research Article

Volume 2 Issue 2

Received Date: July 07, 2018

Published Date: July 23, 2018

\section{Abstract}

This research was aimed at producing erasable ink from locally sourced dye that can compete favourably with available commercial brands. The ink was produced by mixing gum Arabic, ethanol, dye, deionised water and phenolphthalein thoroughly and heating the mixture to $60 \mathrm{oC}$. The ink was then cooled and strained using a filter cloth. Three different ink formulations A, B and C were produced and subjected to physiochemical analysis to ensure that it conformed to standard. The results obtained were $\mathrm{pH}(6.6,2.2$, and 4.3), viscosity (0.001329 Ns/m2, $0.003013 \mathrm{Ns} / \mathrm{m} 2 \mathrm{and} 0.009237 \mathrm{Ns} / \mathrm{m} 2)$ and drying time (6.76 seconds, 9.04 seconds and 15.46 seconds) respectively for samples A, B and C. Samples A and B had the best properties regarding drying time, viscosity, eligibility and erasability. The XRF analysis for the samples proved that the concentrations of the various elements present in the ink is comparable with that of the standard ink available in the market.

Keywords: Ink; Whiteboard; Pigment; Chalk; Schools; Polymer; Dye; Soot; Marker; Erasability; Market

\section{Introduction}

Ink can also be defined as a colloidal system of fine pigment particles dispersed in a solvent [1]. White board markers use erasable ink (also known as dry erase ink) to write on the non-porous and glossy whiteboards. Erasable ink can be cleaned or erased after drying without leaving visible colour residue (also known as streaking) or ghosting so that the surface can be written on again. White board markers have certain advantages over chalk. Thus they are unaffected by water, they can be used on a board by applying less pressure, they erase more easily than chalk, they are cleaner to use than chalk due to the absence of chalk dust, white board markers are healthier to the user than chalk because chalk dust can be hazardous when inhaled [2]. Dry erase ink is similar to permanent marker ink. The major difference between the two is that permanent ink uses an acrylic polymer which helps the colourant stick to surfaces while dry erase ink uses an oily silicon polymer that makes the ink slippery and prevents the colourant from coming in direct contact with the surface [3]. So many institutions are making the switch from chalkboards to whiteboards, therefore the demand for dry erase markers have increased. However, most of the brands used presently are imported from other countries, mainly China. Akande \& Nwosibe [4] clearly stated that producing the ink locally but using synthetic materials that are imported is expensive, hence a need has arisen to replace the materials used in production with locally sourced ones and thus reduce the overall cost of production. Also, some imported whiteboard markers contain xylene and toluene which 


\section{Medicinal \& Analytical Chemistry International Journal}

can be potentially harmful to the health of users. And so most existing inks are pigment based, that is pigments are used as the colourant. The pigments are finely distributed in the ink and are maintained in the suspended state using a dispersing agent [5]. A major disadvantage is that the pigments often precipitate in the ink reservoir. As a result, the pigment content of the ink is reduced and the images written with this ink becomes faint over a relatively short period of time.

In the late 19th century, logwood ink was made from extracts of the logwood (Haematoxyloncampecheartzim) tree mixed with crystallized sodium carbonate and potassium chromate and potassium chromate [6]. The wood was cut into pieces and then steeped in boiled water to extract the dye [7]. They used fine particles of carbon (lampblack) as the colourant and gums, saps or glues as the vehicles or bonding agents Gottensgen and Mark, 2006. Lampblack is the soot collected from oil lamps; however, the lampblack used was created by partially burning tar with a little vegetable oil. The pigment (i.e. lampblack) was suspended in gum or other glue to ensure that it adhered to the writing surface. The erasable or dry erase ink was invented in 1975 by Jerry Woolf of Techform laboratories; however dry erase markers and boards became popular in the mid-1990 [8]. The erasable ink is used to write on enamel-covered white boards or non-porous surfaces in general [9].

Dry erase ink should flow easily so that the marker does not become clogged. The ink must flow readily from the marker, so that the finest lines and character can be formed. It must not be thick or form hard crust when it dries. Dye based ink has lower viscosity than pigment based ink because dyes are dissolved while pigments are dispersed in the resin solution [10]. The drying time affects the erasability of the ink. According to Cueppers \& Christoph [11] they stated that the faster the ink dries the more easily erasable it is. This is because if the drying time is rapid, the ink tends to be attached to the surface and not absorbed by it making it easy to be erased. The ideal drying time for erasable ink is between three and five seconds.

A dye is a coloured, ionising and aromatic substance that has an affinity to the substrate to which it is applied. Dyes are coloured because they absorb some wavelengths of light more than others due to the presence of chromophore. Dyes can either be oil based or water based. Dye consists of small molecules which blends with the water based solution [12].
Dye based inks have lower viscosity than pigment based ink since dyes are dissolved while pigments are suspended or dispersed in the resin solution. Pigment based inks are more expensive than dye based inks and they are less consistent in colour. They also have less colour range than dye based ink. Dye based inks are generally stronger than pigment based inks and can produce much more colour of a given density per unit mass. Another advantage of pigment based inks is that the dye molecules can interact with other ink ingredients, thereby allowing greater benefit when compared to pigmented inks which need optical brighteners and colour enhancing agents to increase the intensity and appearance. The type of pigment used also affects certain ink qualities like the saturation, lightness and hue. Pigments are insoluble in the solvent and have no affinity for the substrate [13]. Pigments have been used predominantly for coloring. Pigments can be organic or inorganic. They are insoluble because they consist of molecules larger than that of dye. Inorganic pigments such as titanium oxide, carbon black, ultramarine blue, cobalt blue, chromium oxide, iron oxide red, and graphite are used. The most common pigment used is carbon black because it gives opacity, colour permanence and vibrancy.

\section{Methodology}

A few lumps of gum Arabic were dissolved in a small amount of deionised water to form a viscous liquid. $4.5 \mathrm{~g}$ of dye was measured using a weighing balance and poured into a beaker containing $20 \mathrm{ml}$ of deionised water to form a solution.

$40 \mathrm{ml}$ of ethanol was measured using a measuring cylinder and added to the solution in a mixer. The solution was stirred to achieve a homogeneous solution. $5 \mathrm{ml}$ of humidified gum Arabic and $2 \mathrm{ml}$ of phenolphthalein was added to the mixture and stirred.

The resulting mixture was heated to $60^{\circ} \mathrm{C}$ using a heating mantle for three minutes while stirring to aid proper reaction mixture and achieve homogeneity. The ink solution was cooled and strained using a filter cloth to remove un-dissolved dye particles. $0.30 \mathrm{~g}$ of magnesium sulphate was measured using a weighing balance and added to $30 \mathrm{ml}$ of the ink to serve as a drying agent.

The resulting ink then was subjected to physiochemical analysis and quality assessment tests to ensure that it conformed to standard. 


\section{Medicinal \& Analytical Chemistry International Journal}

\section{Viscosity}

The ink should flow easily and not clog the marker tip. Ideally, ink should have maximum colour strength at minimum velocity. The time of flow was measured using a flow cup and a stopwatch. A volume of water was allowed to flow freely from a flow cup and the time was noted. Equal volume of the ink was also allowed to flow freely and the time was noted. The viscosity was then calculated using the following relationship between time of flow and viscosity.

$\frac{\text { Time of flow of water }(t)}{\text { Time of flow of ink }(t)}=\frac{\text { Viscosity of water }(\mu)}{\begin{array}{l}\text { Viscosity of ink }(\mu) \\ \text { (McCabe et al, 1986) [14] }\end{array}}$

\section{Drying Time}

After application to the writing surface, the solvent should vapourize quickly leaving the colourant and the binder so that the ink is attached to the surface and not absorbed by it. The ink was used to write on a whiteboard at room temperature and the drying time was measured and recorded using a stopwatch.

The ink should be easily erased without leaving ghosts or coloured residue behind. The ink should be erased without using any cleaning agent like methylated spirit or ethanol. The ink was used to write on a whiteboard, allowed to dry and then erased to determine its erasability.

X-ray fluorescence analysis shows the metals and oxides which are active in the ink mixture. The identity of the element is determined using the energy (wavelength) of the x-ray light (photon) emitted by a particular element.

\section{Results and Discussion}

\section{Discussion of Results}

Table 1 presents the result of the physical analysis carried out on the ink samples. Standard ink 1 and 2 refers to ink samples from imported brands currently available in the market which stand as the standard ink, while samples A, B and C are the ink samples produced from different formulations.

\begin{tabular}{|c|c|c|c|c|c|}
\hline Physical Test & Standard Ink 1 & Standard Ink 2 & Sample A & Sample B & Sample C \\
\hline Erasability & Easily erased & Easily erased & Easily erased & Easily erased & Not easily erased \\
\hline Drying Time(Seconds) & 2.21 & 2.21 & 6.76 & 9.04 & 15.46 \\
\hline Viscosity(N.S/M2) & 0.001147 & 0.00095 & 0.001329 & 0.003013 & 0.00924 \\
\hline Colour & Blue & Black & Red & Black & Green \\
\hline Eligibility & Distinct and clear & Distinct and clear & Distinct and clear & Distinct and clear & $\begin{array}{c}\text { Less distinct and } \\
\text { clear }\end{array}$ \\
\hline pH & 5.5 & 5.5 & 6.6 & 2.2 & 4.3 \\
\hline
\end{tabular}

Table 1: Physical Tests for the Various Ink Samples.

The viscosities of standard ink 1 and 2 are 0.001147 N.s/m2 and 0.000950 N.s $/ \mathrm{m} 2$ respectively and that of samples A, B and C are 0.001329 N.s/m2, 0.003013 N.s/m2 and 0.009237 N.s/m2 respectively as shown in Table 1 . This infers that the viscosity of the ink affects the drying time, therefore, the more viscous the ink, the longer the drying time. Thus viscosities of samples $\mathrm{A}$ and $B$ are closer to standard than sample $C$. The difference in viscosity is due to variations in the quantity of gum Arabic used in the ink formulation.

As indicated in Table 1, the drying time of the standard ink is 2.21 seconds; this is due to the low viscosity of the ink. As a result of this quick drying time and low viscosity, the ink erases quickly. The drying time of samples A, B and $C$ are 6.76 seconds, 9.04 seconds and 15.46 seconds respectively. The drying time of the ink is a function of the viscosity. The drying time of samples $A$ and $B$ are closer to standard than sample $\mathrm{C}$; this is because they have lower viscosities. Low drying time is necessary for easy erasability so that the ink components will stick to the surface instead of being absorbed. The erasability of standard ink is high; the ink samples A and B are easily erased while sample $C$ is not easily erased. This is because of the relatively low viscosities and drying time. The third sample $\mathrm{C}$ does not erase easily because the drying time is long; the quicker the drying time, the easier the erasability. 
The colors of the ink samples are red, black and green for samples A, B, and C respectively. The colour of the ink sample is a derivative of the dye used. The eligibility or distinct nature of the markings is a function of the chemical components of the ink. This will be discussed fully under the chemical analysis as will be seen in Table 2. The eligibility of standard ink is high as the markings are distinct and clear. Samples A and B have high eligibility and the markings are distinct and clear, while the markings by sample $\mathrm{C}$ are less distinct and clear. This is due to the viscous nature of sample $C$ which results in longer drying time of the ink sample.

\begin{tabular}{|c|c|c|}
\hline $\begin{array}{c}\text { Serial } \\
\text { Number }\end{array}$ & Element & $\begin{array}{c}\text { Concentration } \\
\text { (Weight \%) }\end{array}$ \\
\hline 1 & Sodium oxide, $\mathrm{Na}_{2} \mathrm{O}$ & 0 \\
\hline 2 & Magnesium Oxide, $\mathrm{MgO}$ & 0.102 \\
\hline 3 & Aluminium(iii) oxide, $\mathrm{Al}_{2} \mathrm{O}_{3}$ & 3.394 \\
\hline 4 & Silicon (iv) oxide, $\mathrm{SiO}_{2}$ & 40.463 \\
\hline 5 & Phosphorus (v) oxide, $\mathrm{P}_{2} \mathrm{O}_{5}$ & 3.857 \\
\hline 6 & Sulphur (iv) oxide, $\mathrm{SO}_{3}$ & 16.517 \\
\hline 7 & Chlorine, $\mathrm{Cl}$ & 10.675 \\
\hline 8 & Potassium oxide, $\mathrm{K}_{2} \mathrm{O}$ & 0.242 \\
\hline 9 & Calcium oxide, $\mathrm{CaO}$ & 0 \\
\hline 10 & Titanium oxide, $\mathrm{TiO}_{2}$ & 23.437 \\
\hline 11 & Chromium (iii) oxide, $\mathrm{Cr}_{2} \mathrm{O}_{3}$ & 0.792 \\
\hline 12 & Manganese (iii) oxide, $\mathrm{Mn}_{2} \mathrm{O}_{3}$ & 0.399 \\
\hline 13 & Iron (iii) oxide, $\mathrm{Fe} \mathrm{O}_{3}$ & 0.054 \\
\hline 14 & Zinc oxide, $\mathrm{ZnO}$ & 0 \\
\hline 15 & Strontium oxide, $\mathrm{SrO}_{1}$ & 0.067 \\
\hline
\end{tabular}

Table 2: Chemical Test Analysis (Analyte Concentration) for Standard Ink 1 (XRF).

The $\mathrm{pH}$ of standard ink is 5.5 making it slightly acidic. This is due to the presence of Sulphur (VI) Oxide $\mathrm{SO}_{3}$, an acidic gas which is a precursor of $\mathrm{H}_{2} \mathrm{SO}_{4}$. The ink is not highly acidic due to the presence of other basic substances shown in the XRF analysis such as chlorine and magnesium oxide. The $\mathrm{pH}$ of sample $\mathrm{A}$ is 6.6 making it slightly acidic, $\mathrm{pH}$ of sample $\mathrm{B}$ is 2.2 which are acidic and $\mathrm{pH}$ of sample $\mathrm{C}$ is 4.3 which are moderately acidic. The difference in $\mathrm{pH}$ is as a result of the type of dye used, i.e. whether it is oil or water based. Samples A and C are closer to neutrality although sample B can also be used since the ink does not come in bodily contact with the user. Therefore the best ink formulation proves to be sample A.

The ink samples produced were also subjected to chemical analysis. The results are contained in tables 2 to
6 for standard ink 1, 2 and Samples $\mathrm{A}, \mathrm{B}$ and C respectively. The standard ink contains $\mathrm{SiO}_{2}, \mathrm{TiO}_{2}, \mathrm{SO}_{3}, \mathrm{Cl}$, $\mathrm{P}_{2} \mathrm{O}_{5}$ and $\mathrm{Al}_{2} \mathrm{O}_{3}$ as the active ingredients and while $\mathrm{K}_{2} \mathrm{O}$, $\mathrm{MgO}, \mathrm{Cr}_{2} \mathrm{O}_{3}, \mathrm{Mn}_{2} \mathrm{O}_{3}, \mathrm{Fe}_{2} \mathrm{O}_{3}$ and $\mathrm{SrO}$ are contained in minute concentrations. However, $\mathrm{Na}_{2} \mathrm{O}, \mathrm{CaO}$ and $\mathrm{ZnO}$ are absent. The $\mathrm{pH}$ of the ink was seen to be 5.5 from the physical tests in Table 1; this is accounted for by the high percentage of $\mathrm{SO}_{3}$ which is an acidic oxide and chlorine as depicted in Tables $2 \& 3$. The active ingredients in sample A as shown in Table 4 are $\mathrm{SiO}_{2}, \mathrm{SO}_{3}, \mathrm{Cl}, \mathrm{P}_{2} \mathrm{O}_{5}, \mathrm{Al}_{2} \mathrm{O}_{3}, \mathrm{~K}_{2} \mathrm{O}$ and CaO. $\mathrm{MgO}, \mathrm{TiO}_{2} \mathrm{Cr}_{2} \mathrm{O}_{3}, \mathrm{Mn}_{2} \mathrm{O}_{3}, \mathrm{Fe}_{2} \mathrm{O}_{3}, \mathrm{ZnO}$ and $\mathrm{SrO}$. These are contained in small quantities while $\mathrm{Na}_{2} \mathrm{O}$ is absent. The presence of $\mathrm{SO}_{3}$ and chlorine are responsible for the $\mathrm{pH}$ values of the ink. The percentage of $\mathrm{SO}_{3}$ is relatively small which accounts for the slightly acidic value of 6.6. The percentage of $\mathrm{SO}_{3}$ in sample $\mathrm{B}$ shown in Table 5 is $14.057 \%$ the highest hence it accounts for the low $\mathrm{pH}$ value of 2.2 indicated in Table 1.

\begin{tabular}{|c|c|c|}
\hline Serial Number & Element & $\begin{array}{c}\text { Concentration } \\
\text { (Weight \%) }\end{array}$ \\
\hline 1 & $\mathrm{Na}_{2} \mathrm{O}$ & 0 \\
\hline 2 & $\mathrm{MgO}$ & 0 \\
\hline 3 & $\mathrm{Al}_{2} \mathrm{O}_{3}$ & 3.454 \\
\hline 4 & $\mathrm{SiO}_{2}$ & 86.579 \\
\hline 5 & $\mathrm{P}_{2} \mathrm{O}_{5}$ & 6.931 \\
\hline 6 & $\mathrm{SO}_{3}$ & 1.715 \\
\hline 7 & $\mathrm{Cl}$ & 0.704 \\
\hline 8 & $\mathrm{~K}_{2} \mathrm{O}$ & 0.167 \\
\hline 9 & $\mathrm{CaO}$ & 0.238 \\
\hline 10 & $\mathrm{TiO}_{2}$ & 0.03 \\
\hline 11 & $\mathrm{Cr} \mathrm{O}_{3}$ & 0.031 \\
\hline 12 & $\mathrm{Mn}_{2} \mathrm{O}_{3}$ & 0.036 \\
\hline 13 & $\mathrm{Fe}_{2} \mathrm{O}_{3}$ & 0.116 \\
\hline 14 & $\mathrm{ZnO}$ & 0 \\
\hline 15 & $\mathrm{SrO}$ & 0 \\
\hline
\end{tabular}

Table 3: Chemical Test Analysis (Analyte Concentration) for Standard Ink 2 (XRF).

Chromium, magnesium and manganese are heavy metals which are responsible for the toxicity. The percentage of these heavy metals are in minute and negligible quantities in all the ink samples in Tables 4-6 which shows that the ink samples are non-toxic and are therefore friendly to the user health wise. Silicon (iv) oxide has the highest percentage in both the standard and locally produced ink as shown in Tables 2 to 6 . This is because silicone is an anti-caking agent that prevents the ink from precipitating and solidifying with time, it also makes the ink slippery in order to prevent the colourant 
from coming in direct contact with the writing surface. Silicon is also an antifoaming agent that regulates foam efficiency, which prevents the ink from foaming so that the markings can be clear and consistent [15].

\begin{tabular}{|c|c|c|}
\hline Serial Number & Element & $\begin{array}{c}\text { Concentration } \\
\text { (Wt \%) }\end{array}$ \\
\hline 1 & $\mathrm{Na}_{2} \mathrm{O}$ & 0 \\
\hline 2 & $\mathrm{MgO}$ & 0.059 \\
\hline 3 & $\mathrm{Al}_{2} \mathrm{O}_{3}$ & 1.698 \\
\hline 4 & $\mathrm{SiO}_{2}$ & 52.926 \\
\hline 5 & $\mathrm{P}_{2} \mathrm{O}_{5}$ & 17.101 \\
\hline 6 & $\mathrm{SO}_{3}$ & 5.506 \\
\hline 7 & $\mathrm{Cl}$ & 2.895 \\
\hline 8 & $\mathrm{~K}_{2} \mathrm{O}$ & 10.724 \\
\hline 9 & $\mathrm{CaO}$ & 8.763 \\
\hline 10 & $\mathrm{TiO}_{2}$ & 0.021 \\
\hline 11 & $\mathrm{Cr} \mathrm{O}_{3}$ & 0.011 \\
\hline 12 & $\mathrm{Mn}_{2} \mathrm{O}_{3 s}$ & 0.033 \\
\hline 13 & $\mathrm{Fe}_{2} \mathrm{O}_{3}$ & 0.166 \\
\hline 14 & $\mathrm{ZnO}$ & 0.063 \\
\hline 15 & $\mathrm{SrO}$ & 0.034 \\
\hline
\end{tabular}

Table 4: Chemical Test Analysis (Analyte Concentration) for Sample A (XRF).

\begin{tabular}{|c|c|c|}
\hline Serial Number & Element & $\begin{array}{c}\text { Concentration } \\
\text { (Weight \%) }\end{array}$ \\
\hline 1 & $\mathrm{Na}_{2} \mathrm{O}$ & 0 \\
\hline 2 & $\mathrm{MgO}$ & 0 \\
\hline 3 & $\mathrm{Al}_{2} \mathrm{O}_{3}$ & 2.553 \\
\hline 4 & $\mathrm{SiO}_{2}$ & 71.017 \\
\hline 5 & $\mathrm{P}_{2} \mathrm{O}_{5}$ & 7.567 \\
\hline 6 & $\mathrm{SO}_{3}$ & 14.057 \\
\hline 7 & $\mathrm{Cl}$ & 1.848 \\
\hline 8 & $\mathrm{~K}_{2} \mathrm{O}$ & 1.142 \\
\hline 9 & $\mathrm{CaO}$ & 1.356 \\
\hline 10 & $\mathrm{TiO}_{2}$ & 0.044 \\
\hline 11 & $\mathrm{Cr}_{2} \mathrm{O}_{3}$ & 0 \\
\hline 12 & $\mathrm{Mn}_{2} \mathrm{O}_{3}$ & 0.319 \\
\hline 13 & $\mathrm{Fe}_{2} \mathrm{O}_{3}$ & 0.097 \\
\hline 14 & $\mathrm{ZnO}$ & 0 \\
\hline 15 & $\mathrm{SrO}$ & 0 \\
\hline
\end{tabular}

Table 5: Chemical Test Analysis (analyte concentration) for Sample B (XRF).

\begin{tabular}{|c|c|c|}
\hline Serial Number & Element & $\begin{array}{c}\text { Concentration } \\
\text { (Weight \%) }\end{array}$ \\
\hline 1 & $\mathrm{Na}_{2} \mathrm{O}$ & 0.192 \\
\hline 2 & $\mathrm{MgO}$ & 0 \\
\hline 3 & $\mathrm{Al}_{2} \mathrm{O}_{3}$ & 2.083 \\
\hline 4 & $\mathrm{SiO}_{2}$ & 49.385 \\
\hline 5 & $\mathrm{P}_{2} \mathrm{O}_{5}$ & 19.768 \\
\hline 6 & $\mathrm{SO}_{3}$ & 7.235 \\
\hline 7 & $\mathrm{Cl}$ & 4.905 \\
\hline 8 & $\mathrm{~K}_{2} \mathrm{O}$ & 15.188 \\
\hline 9 & $\mathrm{CaO}$ & 0.965 \\
\hline 10 & $\mathrm{TiO}_{2}$ & 0.04 \\
\hline 11 & $\mathrm{Cr}_{2} \mathrm{O}_{3}$ & 0.012 \\
\hline 12 & $\mathrm{Mn}_{2} \mathrm{O}_{3}$ & 0.012 \\
\hline 13 & $\mathrm{Fe}_{2} \mathrm{O}_{3}$ & 0.069 \\
\hline 14 & $\mathrm{ZnO}$ & 0.146 \\
\hline 15 & $\mathrm{SrO}$ & 0 \\
\hline
\end{tabular}

Table 6: Chemical Test Analysis (analyte concentration) for Sample C (XRF).

\section{Conclusion}

From the various findings, the following conclusions were made; the ink produced is a high quality, quick drying erasable ink. Dye and the other locally sourced materials are economically viable for the production of erasable ink. And the ink produced can compete favorably with commercial ink brands presently available in the market. These facts were based on the comparison made on the $\mathrm{pH}$, drying time, viscosity, erasability, eligibility and XRF analysis with those of the standard ink.

\section{Recommendation}

Much research work has not been made on this issue of erasable ink production, so the recommendation would be basically on concern for future research on the subject:

a. Further work should be done to improve the erasability and drying time of the ink.

b. Production of the body of the marker pen should be considered.

\section{References}

1. Ainsworth, Mitchell C (1904) "Inks and their composition and manufacture". Griffin C \& Company limited.

2. Sharon, Huntington J (2004) "Think ink!". Christian Science monitor. 
3. Smith, Joseph A (1992) The pen and ink book: Materials and techniques for today's artists.

4. Akande MT, Nwosibe PO (2012) Production of ink from cashew nut shell liquid. Unpublished HND dissertation, Chemical Engineering Department, Kaduna Polytechnic.

5. Loftin R (1993) Erasable ink. Retrieved 9th December 1993.

6. David A Black (1967) "Fibre tipped pens" 57 Journal of Criminology. L. Criminology \& Police Sci 521.

7. Newman, Lee W (1910) Marking pen, US patent 946149.

8. David N Carvalho's (1904) Forty centuries of Ink, First Edition New York. The Bank Law publishing Co.
9. Baker RW (2000) Kirk-Othmer Encyclopedia of Chemical Technology: Membrane Technology.

10. Cordova A (2008) Washable marker ink composition.

11. Cueppers, Christoph (1989) "On the manufacture of ink" Nepal - Journal of the Department of Archaeology, Number 113, pp: 1-7.

12. Carrol, Clifford C (1997) "US patent US6031023A".

13. Bisset DE (2005) (3rd Edn) The ink manual Van Nostrand Reinhold Co. Ltd, UK, pp: 114-157.

14. McCabe et al. (1986). Momentum Heat and Mass Transfer Fundamentals edited by Robert Greenhorn. 85800004725.

15. Larrie RA, Deardurff A (2013) Erasable inkjet ink composition.

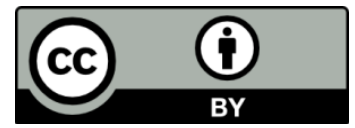

